\title{
Genetic Factors Influencing Human Serum Trehalase Activity
}

\author{
L. C. EZE, M. C. K. TWEEDIE, and D. A. PRICE EVANS \\ From Nuffield Unit of Medical Genetics, Department of Medicine, University of Liverpool
}

Trehalase (EC Number 3.2.1.28; trehalose 1-glucohydrolase) is an enzyme which splits the disaccharide trehalose (1- $\alpha-D-$ glucopyranosyl- $\alpha-D-$ glucopyranoside) to glucose; and it is widely distributed in both plants and animals. It was first discovered by Bourquelot (1893) in Aspergillus niger and since then has been found in bacteria, fungi, yeast, the serum of certain fishes, and in insects (Kalf and Reider, 1958). In mammals trehalase has been found in the intestinal mucosae of hog (Dahlqvist, 1960) and man (McMichael, Webb, and Dawson, 1965), human blood serum (Courtois, Debris, and Georget, 1962), and human kidney cortex (Lukomskaya and Tarasova, 1965; Courtois and Demelier, 1966; Sacktor, 1968; Van Handel, 1968, 1969).

It was observed by Courtois et al. (1962) that the serum trehalase activity of an individual human subject varied very little from one day to another but that there was a large variability between healthy subjects.

The object of the present research was to evaluate possible causes for this large intersubject variability in human serum trehalase activity.

\section{Materials and Methods}

$\alpha \alpha$ Trehalose (B.D.H. Biochemical Reagent); other chemicals were B.D.H. 'Analar' Reagents; acetate buffer; acetic acid/sodium acetate, $p \mathrm{H} 5 \cdot 2,0.5 \mathrm{M}$.

Solutions for 'Technicon' Autoanalyser version of the method of Hoffman (1937) for estimating glucose concentrations were as given in the 'Technicon' Autoanalyser Manual.

Serum samples. $10 \mathrm{ml}$. venous blood were collected from British White volunteer subjects, except where otherwise stated. The blood was allowed to clot, and following retraction the clear serum samples were stored at $-20^{\circ} \mathrm{C}$. to await analysis. The clot was used for red cell $\mathrm{ABO}$ grouping.

Received 28 August 1969.
Saliva samples. Saliva samples collected for ABH secretor typing were obtained by having the subject spit into a test-tube. The quantity collected varied from 2 to $5 \mathrm{ml}$. Artificial stimuli to salivation were not used. The samples were boiled for 10 minutes on a water bath within one hour of collection, centrifuged at about 2000 r.p.m. for 5 minutes, and the supernatants were stored at $-20^{\circ} \mathrm{C}$. to await testing. $A B O$ blood grouping was carried out by means of the standard tube techniques (Lawler and Lawler, 1957).

Determination of salivary ABH secretor status. All salivas were tested for $\mathrm{H}, \mathrm{A}$, and B activity quantitatively by means of doubling dilutions haemagglutination-inhibition technique with $0 \cdot 145 \mathrm{M}$ sodium chloride as diluent. Standard salivas from known O, A, and B secretors and non-secretors were included in each day's estimations.

Estimation of serum trehalase activity was performed by a modification of the method of Courtois et al. (1962). Two incubation mixtures, the test and control, were prepared from each serum sample (Table I).

TABLE I

SOLUTIONS FOR SERUM TREHALASE ESTIMATION

\begin{tabular}{l|c|c}
\hline \multicolumn{1}{c|}{ Constituent } & \multicolumn{2}{|c}{$\begin{array}{c}\text { Incubation } \\
\text { Mixture } \\
\text { (ml.) }\end{array}$} \\
\cline { 2 - 3 } & Test & Control \\
\hline 0.05 M trehalose & $0 \cdot 2$ & Nil \\
$1.0 \%$ sodium fluoride & $0 \cdot 2$ & $0 \cdot 2$ \\
Acetate buffer $p \mathrm{H} 5 \cdot 2,1 \cdot 0 \mathrm{M}$ & $0 \cdot 1$ & $0 \cdot 1$ \\
Serum sample & $0 \cdot 2$ & $0 \cdot 2$ \\
Distilled water & $0 \cdot 3$ & 0.5 \\
\hline
\end{tabular}

Both incubates were kept at $37^{\circ} \mathrm{C}$. in an air oven for six hours. The hydrolysis of trehalose was halted by placing the tubes at $-20^{\circ} \mathrm{C}$. to await assay. Sodium fluoride prevents glycolysis of glucose either present originally in the serum or liberated by hydrolysis of trehalose.

Glucose assay was performed using the technique of Hoffman (1937) as adapted to the 'Technicon' Autoanalyser. Pump speed was 40 samples per hour. A water cup was placed following each sample cup. An 
array of standards at $25,50,100,150,200$, and 250 mg. glucose per $100 \mathrm{ml}$. concentration was run before and after each batch of unknowns. The difference between test and control incubates indicated glucose liberated by trehalase activity. The enzyme activity is expressed according to the rules established by the International Union of Chemistry and Biochemistry: 'One unit of trehalase activity is equal to one micromole of trehalose hydrolysed in one minute by one litre of serum.'

Random subjects. Donors of blood for transfusion were asked to provide a specimen of saliva. At the end of blood donation a $10 \mathrm{ml}$. sample of blood was obtained from each subject before the venous cannula was removed. Serum samples from the first 20 male $O$ secretors, the first 20 male $O$ non-secretors, etc. were eventually analysed for trehalase activity. The experiment was terminated when 20 persons in each of the 8 phenotypic categories shown in Table II had been examined.

Subjects for investigation of effect of food on serum trehalase activity. These subjects were university laboratory and other staff and hospital staff whose $\mathrm{ABO}$ blood group and salivary $\mathrm{ABH}$ secretor status was already known.

\section{TABLE II}

MEAN, STANDARD DEVIATION (SD), AND STANDARD ERROR OF MEAN (SEM) OF LOG 10 (10 $\times$ SERUM TREHALASE ACTIVITY IN UNITS) IN VARIOUS PHENOTYPIC CATEGORIES (20 SUBJECTS IN EACH)

\begin{tabular}{l|c|c|c|c|c|c}
\hline \multirow{2}{*}{ Phenotype } & \multicolumn{3}{c|}{ Male } & \multicolumn{3}{c}{ Female } \\
\cline { 2 - 4 } \cline { 5 - 7 } & Mean & SD & SEM & Mean & SD & SEM \\
\hline O secretor & 2.07 & 0.34 & 0.075 & 1.83 & 0.44 & 0.098 \\
O non-secretor & 1.94 & 0.40 & 0.089 & 1.66 & 0.40 & 0.089 \\
A secretor & 2.09 & 0.30 & 0.068 & 2.02 & 0.29 & 0.064 \\
A non-secretor & 2.06 & 0.33 & 0.074 & 2.05 & 0.32 & 0.072 \\
& & & & & & \\
\hline
\end{tabular}

TABLE IIa

GEOMETRIC MEAN AND FACTORS CORRESPONDING TO SD AND SEM OF SERUM TREHALASE ACTIVITY IN UNITS, OBTAINED BY TAKING
ANTILOGARITHMS OF RESULTS GIVEN IN TABLE II

\begin{tabular}{|c|c|c|c|c|c|c|}
\hline \multirow[b]{2}{*}{ Phenotype } & \multicolumn{3}{|c|}{ Male } & \multicolumn{3}{|c|}{ Female } \\
\hline & $\begin{array}{l}\text { Geom. } \\
\text { Mean } \\
\text { (units) }\end{array}$ & $\begin{array}{c}\text { SD } \\
\text { Factor }\end{array}$ & $\underset{\text { Factor }}{\text { SEM }}$ & $\begin{array}{l}\text { Geom. } \\
\text { Mean } \\
\text { (units) }\end{array}$ & $\underset{\text { Factor }}{\text { SD }}$ & $\underset{\text { Factor }}{\text { SEM }}$ \\
\hline $\begin{array}{l}\text { O secretor } \\
\text { O non-secretor } \\
\text { A secretor } \\
\text { A non-secretor }\end{array}$ & $\begin{array}{r}11 \cdot 75 \\
8 \cdot 70 \\
12 \cdot 27 \\
11 \cdot 55\end{array}$ & $\begin{array}{l}2 \cdot 18 \\
2 \cdot 52 \\
2 \cdot 02 \\
2 \cdot 15\end{array}$ & $\begin{array}{l}1 \cdot 19 \\
1 \cdot 23 \\
1 \cdot 17 \\
1 \cdot 19\end{array}$ & $\begin{array}{r}6 \cdot 79 \\
4.57 \\
10.54 \\
11 \cdot 28\end{array}$ & $\begin{array}{l}2 \cdot 76 \\
2 \cdot 52 \\
1 \cdot 94 \\
2 \cdot 12\end{array}$ & $\begin{array}{l}1 \cdot 25 \\
1 \cdot 23 \\
1 \cdot 16 \\
1 \cdot 18\end{array}$ \\
\hline
\end{tabular}

First test meal. $10 \mathrm{ml}$. venous blood were taken from the fasting subject who then consumed a standard breakfast meal between 8 a.m. and 9 a.m., consisting of two slices of toast spread with marmalade (but no butter) and one cup of tea containing a minimal amount of milk. Venous blood was taken at 2 and $\mathbf{4}$ hours after the meal, the subject having taken no other food or drink apart from tap water during this time.

Second test meal. On another occasion, at least a week later, $10 \mathrm{ml}$. venous blood were taken from the fasting subject, who then consumed a standard breakfast meal between 8 a.m. and 9 a.m., consisting of two slices of toast thickly spread with butter, with marmalade, and tea. Venous blood was taken at 2 and 4 hours after the meal, the subject again having taken no further food or drink apart from tap water.

Family studies. Twenty-nine two-generation family units (28 British, 1 African) comprising mother, father, and a variable number of offspring have been studied. Propositi were healthy university staff and friends, and none was ascertained because of being known to have any disease condition. Non-fasting venous blood samples were taken when convenient to the subjects concerned. Only one observation was made on each individual in the family study. Statistical methods

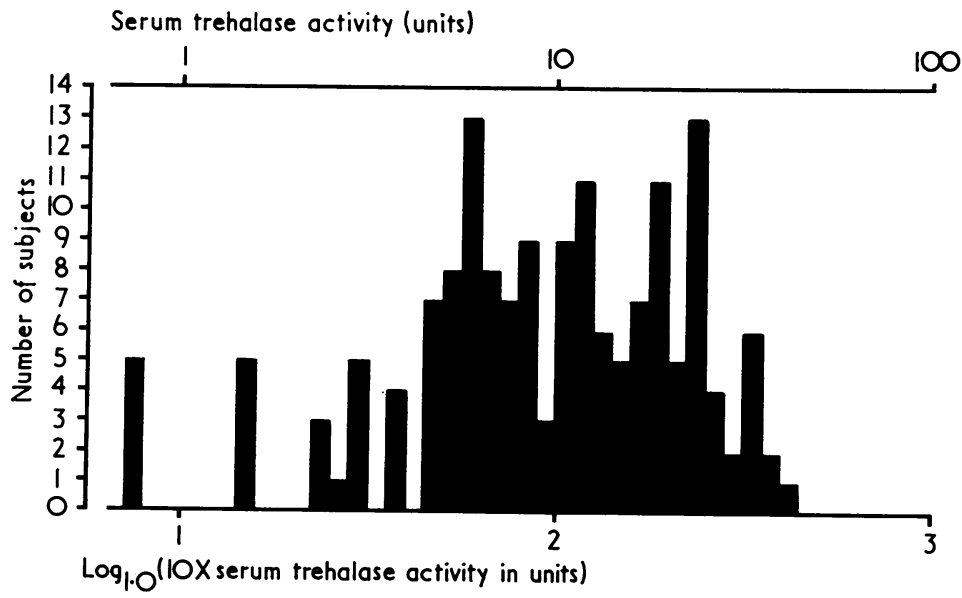

FIG. 1. Frequency distribution histogram of serum trehalase activities in the 160 subjects recorded in Table II. 
TABLE III

ANALYSIS OF VARIANCE OF LOG $_{10}(10 \times$ SERUM TREHALASE ACTIVITY)

\begin{tabular}{|c|c|c|c|c|}
\hline Item & $\begin{array}{l}\text { Degrees } \\
\text { of } \\
\text { Freedom }\end{array}$ & $\begin{array}{l}\text { Sums of } \\
\text { Squares }\end{array}$ & $\begin{array}{c}\text { Mean } \\
\text { Squares }\end{array}$ & $\begin{array}{c}\text { Variance } \\
\text { Ratio }\end{array}$ \\
\hline \multirow{4}{*}{$\begin{array}{l}\text { Blood group }{ }^{\star} \\
\text { ABH secretor status } \\
\text { Sex } \\
\text { Blood group } \times \text { secretor } \\
\text { status } \\
\text { Sex } \times \text { blood group }{ }^{\star} \\
\text { Secretor status } \times \text { sex } \\
\text { Blood group } \times \text { sex } \times \\
\text { secretor status } \\
\text { Residual }\end{array}$} & $\begin{array}{l}1 \\
1 \\
1\end{array}$ & $\begin{array}{l}1 \cdot 3111 \\
0 \cdot 2235 \\
0 \cdot 8807\end{array}$ & $\begin{array}{l}1 \cdot 3111 \\
0.2235 \\
0 \cdot 8807\end{array}$ & $\begin{array}{r}10.2430 \\
1.7461 \\
6.8805\end{array}$ \\
\hline & $\begin{array}{l}1 \\
1 \\
1\end{array}$ & $\begin{array}{l}0.2236 \\
0.4864 \\
0.0005\end{array}$ & $\begin{array}{l}0.2236 \\
0.4864 \\
0.0005\end{array}$ & $\begin{array}{c}1.7469 \\
3.800 \\
-\end{array}$ \\
\hline & $\begin{array}{r}1 \\
152\end{array}$ & $\begin{array}{r}0.0231 \\
19.4552\end{array}$ & $\begin{array}{l}0.0231 \\
0.1280\end{array}$ & - \\
\hline & 159 & $22 \cdot 6041$ & & \\
\hline
\end{tabular}

$\star$ Blood group (A or $\mathbf{O}$ ).

were standard (Snedecor, 1956). The computations were done on the logarithm, to the base 10 , of ten times the serum trehalase activities (units). This transformation normalized the data (see Fig. 1) and also resulted in reasonably constant variances in the various groups (see, for example, Table II). The factor 10 , by which the measured values in the standard units were multiplied before taking the logarithms, avoided the introduction of negative logarithms. It has no effect on the variances. Four figure logarithms were used to compute Tables III and $V$, but have been contracted to two places of decimals in Tables II and IV.

\section{Results}

Random subjects. The arithmetic means, standard deviations, and standard errors of the

TABLE V

HIERARCHICAL ANALYSIS OF VARIANCE OF LOG (10 $\times$ SERUM TREHALASE ACTIVITY IN UNITS $)$ FROM THE FEEDING EXPERIMENT

\begin{tabular}{|c|c|c|c|c|c|}
\hline $\begin{array}{l}\text { Source of } \\
\text { Variation }\end{array}$ & $\begin{array}{c}\text { Degrees } \\
\text { of } \\
\text { Freedom }\end{array}$ & $\begin{array}{l}\text { Cor- } \\
\text { rected } \\
\text { Sum of } \\
\text { Squares }\end{array}$ & $\begin{array}{c}\text { Mean } \\
\text { Square }\end{array}$ & $\begin{array}{c}\text { Contri- } \\
\text { bution } \\
\text { to } \\
\text { Vari- } \\
\text { ance }\end{array}$ & $\begin{array}{c}\text { Per- } \\
\text { centage } \\
\text { of } \\
\text { Vari- } \\
\text { ance }\end{array}$ \\
\hline $\begin{array}{l}\text { Phenotype } \\
\text { Persons, within } \\
\text { phenotypes } \\
\text { Occasions or } \\
\text { diets, within } \\
\text { persons } \\
\text { Times, within } \\
\text { diets and } \\
\text { persons }\end{array}$ & $\begin{array}{r}3 \\
20 \\
24 \\
96\end{array}$ & $\begin{array}{r}1.3398 \\
22.1212 \\
0.1393 \\
0.0892\end{array}$ & $\left.\begin{array}{l}0.4466 \\
1.1061\end{array}\right\}$ & $\begin{array}{l}0.16904 \\
0.00163 \\
0.00093\end{array}$ & $\begin{array}{l}0.95 \\
0.54\end{array}$ \\
\hline & 143 & $23 \cdot 6895$ & & 0.17159 & $100 \cdot 00$ \\
\hline
\end{tabular}

TABLE IV

LOG $_{10}(10 \times$ SERUM TREHALASE ACTIVITY IN UNITS) BEFORE AND AFTER EATING IN SUBIECTS OF VARIOUS PHENOTYPIC CATEGORIES (EACH ROW REPRESENTS ONE INDIVIDUAL)

\begin{tabular}{|c|c|c|c|c|c|c|c|c|}
\hline \multirow[b]{2}{*}{ Sex } & \multirow[b]{2}{*}{$\begin{array}{l}\text { ABO } \\
\text { Blood } \\
\text { Group }\end{array}$} & \multirow[b]{2}{*}{$\begin{array}{l}\text { Salivary ABH } \\
\text { Secretor Status }\end{array}$} & \multicolumn{6}{|c|}{ LOG $_{10}(10 \times$ Serum Trehalase Activity in Units $)$} \\
\hline & & & $\begin{array}{l}\text { First } \\
\text { Fasting }\end{array}$ & \begin{tabular}{|}
2 Hours \\
After \\
Non-fat \\
Meal
\end{tabular} & $\begin{array}{l}4 \text { Hours } \\
\text { After } \\
\text { Non-fat } \\
\text { Meal }\end{array}$ & $\begin{array}{l}\text { Second } \\
\text { Fasting }\end{array}$ & \begin{tabular}{|c|}
2 Hours \\
After \\
Fatty \\
Meal
\end{tabular} & $\begin{array}{l}4 \text { Hours } \\
\text { After } \\
\text { Fatty } \\
\text { Meal }\end{array}$ \\
\hline \multirow[t]{2}{*}{ Male } & $\mathbf{O}$ & $\begin{array}{c}\text { Secretor } \\
\text { Non-secretor } \\
\text { ", }\end{array}$ & $\begin{array}{l}1 \cdot 82 \\
2 \cdot 00 \\
1 \cdot 98 \\
2 \cdot 51\end{array}$ & $\begin{array}{l}1 \cdot 76 \\
1 \cdot 97 \\
2 \cdot 00 \\
2 \cdot 50\end{array}$ & $\begin{array}{l}1.82 \\
1.97 \\
2.03 \\
2.51\end{array}$ & $\begin{array}{l}1.67 \\
1.91 \\
1.89 \\
2.53\end{array}$ & $\begin{array}{l}1 \cdot 79 \\
1 \cdot 97 \\
2 \cdot 02 \\
2 \cdot 52\end{array}$ & $\begin{array}{l}1.73 \\
1.95 \\
1.97 \\
2.56\end{array}$ \\
\hline & & Mean & $2 \cdot 08$ & $2 \cdot 06$ & $2 \cdot 08$ & $2 \cdot 00$ & $2 \cdot 07$ & $2 \cdot 05$ \\
\hline \multirow[t]{2}{*}{ Male } & A & $\begin{array}{c}\text { Secretor } \\
\text { ", } \\
\text { ", } \\
\text { Non-secretor } \\
\text { ", }\end{array}$ & $\begin{array}{l}1 \cdot 19 \\
2 \cdot 25 \\
1.95 \\
1.89 \\
2.57 \\
0.89 \\
2 \cdot 48 \\
2.05\end{array}$ & $\begin{array}{l}1 \cdot 19 \\
2 \cdot 23 \\
1.93 \\
1 \cdot 86 \\
2 \cdot 58 \\
0 \cdot 89 \\
2 \cdot 49 \\
1.95\end{array}$ & $\begin{array}{l}1.19 \\
2.25 \\
1.95 \\
1.91 \\
2.56 \\
0.89 \\
2.47 \\
1.98\end{array}$ & $\begin{array}{l}1.43 \\
2.22 \\
1.91 \\
1.89 \\
2.56 \\
1.06 \\
2.46 \\
2.00\end{array}$ & $\begin{array}{l}1.36 \\
2.21 \\
1.97 \\
1.89 \\
2.57 \\
1.06 \\
2.46 \\
1.91\end{array}$ & $\begin{array}{l}1.29 \\
2.25 \\
1.89 \\
1.89 \\
2.56 \\
1.06 \\
2.51 \\
1.97\end{array}$ \\
\hline & & Mean & $1 \cdot 91$ & $1 \cdot 89$ & $1 \cdot 90$ & $1 \cdot 94$ & 1.93 & $1 \cdot 93$ \\
\hline \multirow[t]{2}{*}{ Female } & $\mathbf{O}$ & $\begin{array}{c}\text { Secretor } \\
\text { " } \\
\text { ", } \\
\text { Non-secretor } \\
\text { ", } \\
\text { " }\end{array}$ & $\begin{array}{l}1 \cdot 70 \\
2 \cdot 12 \\
2.41 \\
2.09 \\
1.54 \\
1.59 \\
1.95 \\
2 \cdot 12 \\
\end{array}$ & $\begin{array}{l}1.67 \\
2.09 \\
2.39 \\
2.09 \\
1.54 \\
1.63 \\
1.84 \\
2.09\end{array}$ & $\begin{array}{l}1 \cdot 73 \\
2 \cdot 12 \\
2 \cdot 39 \\
2 \cdot 13 \\
1 \cdot 63 \\
1.63 \\
1.87 \\
2 \cdot 15\end{array}$ & $\begin{array}{l}1.67 \\
2 \cdot 10 \\
2 \cdot 35 \\
2 \cdot 13 \\
1.63 \\
1.63 \\
1.84 \\
2.12\end{array}$ & $\begin{array}{l}1 \cdot 67 \\
2 \cdot 14 \\
2 \cdot 36 \\
2 \cdot 09 \\
1 \cdot 63 \\
1 \cdot 54 \\
1 \cdot 82 \\
2 \cdot 15\end{array}$ & $\begin{array}{l}1 \cdot 70 \\
2 \cdot 13 \\
2 \cdot 39 \\
2 \cdot 12 \\
1 \cdot 59 \\
1 \cdot 54 \\
1 \cdot 84 \\
2 \cdot 13\end{array}$ \\
\hline & & Mean & $1 \cdot 94$ & 1.92 & 1.96 & $1 \cdot 93$ & 1.93 & 1.93 \\
\hline \multirow[t]{2}{*}{ Female } & $\mathbf{A}$ & $\begin{array}{c}\text { Secretor } \\
\text { Non-secretor } \\
\text { ", } \\
\text { " }\end{array}$ & $\begin{array}{l}2 \cdot 47 \\
2 \cdot 06 \\
2 \cdot 09 \\
1 \cdot 19 \\
\end{array}$ & $\begin{array}{l}2 \cdot 38 \\
2 \cdot 05 \\
2 \cdot 03 \\
1 \cdot 19\end{array}$ & $\begin{array}{l}2 \cdot 49 \\
2 \cdot 05 \\
2 \cdot 05 \\
1 \cdot 19\end{array}$ & $\begin{array}{l}2 \cdot 46 \\
2 \cdot 06 \\
2 \cdot 06 \\
1 \cdot 29 \\
\end{array}$ & $\begin{array}{l}2 \cdot 47 \\
2 \cdot 08 \\
2 \cdot 09 \\
1 \cdot 29\end{array}$ & $\begin{array}{l}2 \cdot 48 \\
2 \cdot 08 \\
2 \cdot 09 \\
1 \cdot 29\end{array}$ \\
\hline & & Mean & $1 \cdot 95$ & 1.91 & 1.95 & 1.97 & 1.98 & 1.99 \\
\hline
\end{tabular}


logarithmic serum trehalase values in the various phenotypic categories are shown in Table II. The estimate of the standard deviation within phenotypic categories is 0.358 . Table IIa shows the antilogarithms of the results calculated in Table II.

An analysis of variance has been performed and the results are shown in Table III. Sex and blood group are significant factors, males tending to have higher values than females and A subjects higher levels than $O$ subjects (see Table II). Salivary $\mathrm{ABH}$ secretion is not a factor of significance.

From the analysis in Table III it can be estimated that of the total variance of the selected population tested in this experiment about $10 \%$ is due to blood group (O/A) and about $6 \%$ is due to sex.

Effect of diet. The results are presented in Table IV. Simple inspection of the data reveals how constant the serum trehalase activity is in a given individual and that it is not affected in any systematic manner by ingestion of either non-fatty or fatty foods. This view is borne out by analysis of variance.

The sex of the subjects was not taken account of in the design of the feeding experiments, and in consequence the phenotypic groups contained varying numbers of the two sexes. Though there was an indication in the previous experiment (Table III) of a sex factor effect, it was not felt to be sufficiently large to warrant a more complicated analysis than is shown in Table V.

The main conclusion from this experiment was that the 'repeatability' (see Falconer, 1960) without reference to phenotype was roughly $98.5 \%$ (Table V). Other main factors and interactions investigated in this experiment yielded no significant contributions to the total variance.

Since sex was included as a source of variation between persons, the 'repeatability' would presumably have been even higher if the analysis had been performed separately for males and females.

Heredity. There is a significant regression of uncorrected mean-offspring value on mid-parent value of $\log _{10}(10 \times$ serum trehalase activity $)$ in 29 families (Fig. 2). The regression coefficient $b=$ 0.58 , standard error of $b=0.22$, intercept a (i.e. $y$ when $x=0$ ) $=0.74$, correlation coefficient $r=0.45, t$ to test significance of $b$ or $r$ is 2.62 and $p<0.02$. The regression coefficient gives an estimate of 'heritability' of $58 \%$.

Serum trehalase activity appeared to rise up to the age of about 20 years. This observation is borne out by finding a significant linear regression of serum trehalase activity on age (up to 20 years) in

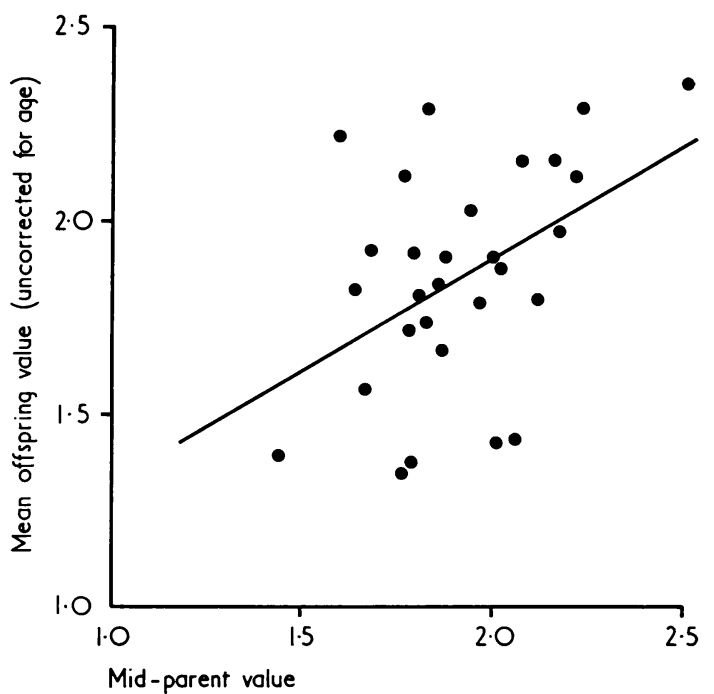

FIG. 2. Regression of mean offspring values of serum trehalase activity upon the mid-parent value [both in the transformation $\log _{10}(10 \times$ serum trehalase activity in units $\left.)\right]$.

both male and female offspring. Whether this relation was due to body weight rather than to age could not be investigated as weights were not recorded during this study. No significant regression of trehalase activity upon age was found in either male parents or female parents. An agecorrected trehalase activity was computed for offspring aged 20 years and below. The score for each offspring was adjusted to 20 years of age, using the calculated regression of male and female offspring $\log _{10}(10 \times$ trehalase activity $)=y$, on age in years $=x ; n=54, b=0.025, a=1.54, r=0.48, t=$ $3.94, \mathrm{p}<0.001$. This age-corrected value was used in computation and was found to make little difference to the heritability regression $(b=0.57)$.

There was no significant correlation between female parent enzyme activity and male parent activity $(n=29, r=-0.24, t=-1 \cdot 13, \mathrm{p}>0 \cdot 10)$.

There is evidence that the 24 subjects for the feeding experiment were drawn from the population as represented by Table II. The arithmetic mean of the $\log _{10}$ ( $10 \times$ serum trehalase activity) of the first fasting value for the 24 subjects is 1.95 , and the estimate of the mean for the population is 1.97 and the variance estimates are, respectively, 0.19 and $0 \cdot 14$.

The family parents are a sample of unrelated adults and the mean serum trehalase activity for these 58 subjects is 1.92 and the variance $0 \cdot 13$. The families can, therefore, be considered to be representative of the general population. 


\section{Discussion}

The results clearly indicate that the genetic characters, sex, and ABO blood group made small but significant contributions to the variance of serum trehalase activity in the human population. Salivary ABH secretor phenotype has not been shown to exert a significant effect.

Feeding fatty or non-fatty food had no significant effect upon the serum trehalase activity under the conditions of the experiment. Though the effect of feeding was only followed for 4 hours, it seems unlikely that fasting (or feeding) status would have influenced the variance of the serum enzyme activity observed in the population survey. Nevertheless, no systematic observations have been undertaken by us to establish the constancy of serum trehalase activity over a long period of time of months or years, and it is possible that the relative levels of activity in different people could change substantially over such a period.

Trehalase is found in the jejunal mucosal epithelial cell (Borgström and Dahlqvist, 1958; McMichael et al., 1965). Alkaline phosphatase from this same location is found in the sera of blood group $O$ and $B$ (but not $A$ ) subjects, and in the sera of secretors but not of non-secretors; and its concentration rises after fat ingestion (Langman et al., 1966). It has been suggested that this rise is due to a greater permeability of the cell membrane allowing enzyme molecules to escape more easily from the cell (Langman et al., 1966). The fact that trehalase did not behave in a similar manner is evidence against the hypothesis.

The regression coefficient computed for meanoffspring serum trehalase activity (y) upon midparent serum trehalase activity $(x)$ gives an estimate of 'heritability'. Heritability has been defined as 'the ratio of additive genetic variance to phenotypic variance' (Falconer, 1960). Since the families appear to be representative of the population it seems that about $58 \%$ of the variance observed for this serum enzyme activity in the population is due to additive genetic factors. About $1 \%(0.95 \%+$ $0.54 \%$; Table V) of the variance observed for this serum enzyme activity in the population is associated with temporary (short-term) 'environment' or errors of measurement. The remaining approximately $40 \%$ could be due to: (1) longer term 'environmental' changes within individuals and (2) non-additive genetic differences between individuals (Falconer, 1960).

Sex and ABO blood group have been shown to be minor components of the polygenic system controlling serum trehalase activity, but the other components are as yet unknown. The kidney cortex contains the highest activity of trehalase in many mammals including Man (Courtois and Demelier, 1966), and it would be of interest to know if the enzyme at that site exhibits genetic polymorphism.

\section{Summary}

Trehalase is an enzyme which splits the disaccharide trehalose yielding glucose. This enzyme is found in human serum and there is a large variability between subjects but little variation in one subject from one day to another.

Three experiments have been performed to try and find out why this serum enzyme activity varies so much between subjects. First, to see if any of the three factors sex, ABO blood group, and salivary $\mathrm{ABH}$ secretor status make any significant contribution to the variance. The first two factors were found to make a small but significant contribution but secretor status did not. Secondly, to see if eating fatty or non-fatty foods significantly affected the serum trehalase activity. No significant effect was observed. The short term 'repeatability' of serum trehalase activity within an individual was $98.5 \%$. Thirdly, families have been studied to see to what extent serum trehalase activity is a genetically determined character. A heritability of about $58 \%$ was found.

It was concluded that serum trehalase activity was under polygenic control; and that two genetic factors making small but significant contributions to this polygenic system were sex and $\mathrm{ABO}$ blood group.

The authors acknowledge the following. The United Liverpool Hospital Medical Research Committee (Chairman, Professor C. A. Clarke, C.B.E.) and the Nuffield Trust (via Professor C. A. Clarke, C.B.E.) for generous financial support. Dr. D. Lehane, Director, Liverpool Regional Blood Transfusion Service, for providing access to blood donors. Miss M. F. Bullen, S.R.N., for performing the feeding experiment. Mr. W. T. A. Donohoe, for secretor typing and blood grouping. Miss J. Lomath and Miss R. Hillary for technical assistance.

\section{REFERENCES}

Borgström, B., and Dahlqvist, A. (1958). Cellular localization. Solubilization and separation of intestinal glycosidases. Acta Chemica Scandavica, 12, 1997-2006.

Bourquelot, E. (1893). Transformation du tréhalose en glucose dans les Champignons par un ferment soluble: la tréhalase. Bulletin de la Société Mycologique de France, 9, 189-194.

Courtois, J. E., Debris, M., and Georget, J. C. (1962). Mise en évidence d'une tréhalase dans le sérum humain. Bulletin de l'Académie Nationale de Médecine, 146, 599-602.

l', and Demelier, J. F. (1966). Réparatition de la tréhalase chez l'homme et quelques mammifères. Bulletin de la Société de Chimie Biologique, 48, 277-286.

Dahlqvist, A. (1960). Characterization of hog intestinal trehalase. Acta Chemica Scandavica, 14, 9-16.

Falconer, D. S. (1960). Introduction to Quantitative Genetics, pp. 143 and 165. Oliver and Boyd, Edinburgh. 
Hoffman, W. S. (1937). A rapid photoelectric method for the determination of glucose in blood and urine. Fournal of Biological Chemistry, 120, 51-55.

Kalf, G. F., and Reider, S. V. (1958). The purification and properties of trehalase. ibid., 230, 691-698.

Langman, M. J. S., Leuthold, E., Robson, E. B., Harris, J., Luffman, J. E., and Harris, H. (1966). Influence of diet on the 'intestinal' component of serum alkaline phosphatase in people of different ABO blood groups and secretor status. Nature (London), 212, 4143.

Lawler, S. D., and Lawler, L. J. (1957). Human Blood Groups and Inheritance, 2nd ed., Chapter 2. Heinemann, London.

Lukomskaya, I. S., and Tarasova, G. I. (1965). Trehalase of vertebrates and man. Biokhimiya, 30, 95-99.
McMichael, H. B., Webb, J., and Dawson, A. M. (1965). Lactase deficiency in adults: a cause of 'functional' diarrhoea. Lancet, 1, 717-720.

Sacktor, B. (1968). Trehalase and the transport of glucose in the $\stackrel{+}{\longrightarrow}$ mammalian kidney and intestine. Proceedings of the National Academy of Sciences of the United States of America, 60, 1007-1014. O

Snedecor, G. W. (1956). Statistical Methods Applied to Experiments in Agriculture and Biology, 5th ed. Iowa State University Press, Ames, Iowa.

Van Handel, E. (1968). Trehalase and maltase in the serum of $\frac{\bar{S}}{\partial}$ vertebrates. Comparative Biochemistry and Physiology, 26, 561566.

(1969). Do trehalose and trehalase function in renal glucose transport? Science, 163, 1075-1076. . 